\title{
The quality of nursing care regarding personal hygiene of patients admitted to a selected hospital in the Kavango region
}

\author{
A van Dyk, D.Cur, Department of Nursing, University of Namibia \\ LF Small, D.N.Sc, Department of Nursing, University of Namibia \\ T vd Merwe, D.Cur, Formerly from the Department of Nursing, University of \\ Stellenbosch \\ M Mueyu, M.NSc, Department of Nursing, University of Namibia
}

\section{Abstract}

The aim of the study was to determine the quality of nursing care regarding personal hygiene of patients admitted to a hospital in the Kavango region of Namibia.

The study was prompted by repeated media reports over the radio. Commentators and listeners expressed concern over the seeming lack of adequate hygienic measures, specifically with regard to patient care.

To objectively quantify and describe the extent of this problem, a single objective was stated, namely to measure the quality of nursing care with regard to patient hygiene. A descriptive survey design was chosen to explore and describe the problem. A check-list was developed to observe thirty patients (the total population) over a period of one week.

The results indicated that certain aspects of hygienic care needed improvement.

These aspects (parts) were the care of male patient's beards; perineal care; and mouth care.

Other aspects of care were indirectly negatively influenced due to incomplete record keeping.

On completion of the study recommendations were made with regard to in-service education, management and research.

\section{Opsomming}

Die doel van die studie was om die gehalte van higiëniese versorging gelewer aan pasiënte in ' $n$ bepaalde hospital in die Kavango, Namibië, te bepaal.

Die studie het voortgevloei uit verslaggewing deur die media, koerante en die radio, oor die skynbare gebrek aan higiëniese maatreëls, veral ten opsigte van pasiënt versorging.

Om die probleem te kwantitiseer en te beskryf is " $n$ enkele doelwit gestel, naamlik om die verpleegsorg van pasiënte te meet, en spesifiek ten opsigte van higiëne. Om die probleem te ondersoek en beskryf, is van " $n$ beskrywende opname ontwerp gebruik gemaak. Met behulp van ' $n$ kontrole lys is dertig pasiënte (die totale populasie) oor 'n tydperk van een week observeer.

Uit die resultate het dit geblyk dat sekere higiëniese aspekte aandag moet geniet naamlik die versorging van manlike pasiënte se baarde, perineale versorging en mondsorg.

Onvolledige verslaggewing (rekordhouding) het indirek negatief ingewerk op sekere aspekte van versorging.

$\mathrm{Na}$ voltooing van die studie is aanbevelings gemaak ten opsigte van indiensopleiding, bestuur en navorsing.

\section{Introduction and background to the problem}

Personal hygiene may be regarded as the "self-care" by which people maintain health (Oxford Dictionary, 1990: 579).
Hygiene is a highly personal matter determined by individual values and practices. It is influenced by culture, social, familial and individual factors, as well as by the person's knowledge of health and hygiene (Young, Van Niekerk \& Mogotlane, 2003: 97-98).

When people are ill, hygiene practices frequently become 
secondary to other functions, such as maintaining an open airway, breathing and circulation. They also lack the energy for simple everyday activities like bathing, or brushing their teeth. This is where the nurse is to support and assist the patient.

It seemed that this was not always the case, as the researcher heard negative comments over the radio regarding hygiene care in hospitals in the Kavango region.

Some of these comments were that:

- $\quad$ Patients were not bathed

- Mouth care was neglected

- Nails and hair were not cared for, and that the

- Environment was not always clean

This lead to the following research question:

What is the current quality of basic nursing care specifically with regard to personal hygiene of patients in a selected hospital in the Kavango region?

\section{Study objective}

One objective was stated, namely:

To measure the quality of nursing care, with regard to certain aspects concerning personal hygiene of patients in a selected hospital in the Kavango region.

\section{Research design}

A descriptive survey by means of a checklist was utilized. The population consisted of all the patients admitted to a specific hospital in the Kavango region for a period longer than seven (7) days at a specific time. Thirty (30) patients met these criteria. This was a very specific population that met these criteria, namely hemiplegic patients, HIV/AIDS patients and patients who had amputations.

Due to the small population size, all these patients were included with no need for sampling. Thus the total population was used. These patients were observed over a period of seven (7) days during which time 210 observations were conducted. The data collection started after the first seven days of hospitalization.

A checklist was used as research instrument. The checklist items were formulated based on the objective of the study and the specific information sought. The literature on hygiene was studied and the Scope of Practice for Registered Nurses as well as Henderson's theory on human needs was examined (Namibia, 1993: 1-10; Young et al, 2003: 94 95). Relevant aspects were extracted.

For validity the checklist was submitted to five (5) registered nurses who made suggestions were necessary, specifically with regard to face and content validity

The instrument yielded also the same responses when used by a different researcher on the same patient. This was done to determine consistency and accuracy of the instrument as part of an evaluation of the reliability.

\section{Pilot study}

Before distribution, the checklist was pretested. Pretesting was done by selecting five (5) registered nurses from this specific hospital. They were selected purposively because of their managerial positions and clinical skills. These five (5) registered nurses agreed on the type of items and the format of the checklist. They all agreed upon the face validity of the instrument.

Four (4) patients were selected for the pilot study. These four (4) patients were the only patients available during the period of a month before the initiation of the main study that met the inclusion criteria for the population. Only technical changes like the wording of questions were necessary after completion of the pilot study.

\section{Data analysis and interpretation}

Data to be analyzed contained information on the biographical background as well as items that evaluated the quality of hygiene and specifically the following aspects:

\begin{tabular}{ll} 
- & Hair care \\
- & Eye care \\
- & Mour care \\
- & Nose care \\
- & Skin care \\
- & Beard care \\
- & Hands, nail and foot care \\
\hline
\end{tabular}

These "aspects" were based on the scope of practice . (Namibia, 1993: 1-10) and Henderson's theory on human needs (Young et al., 2003: 94 - 95).

\section{Biographical information}

Although biographical information was not the focus of this study, it was included because variables such as gender and age might have an effect on the hygiene needs of patients.

Twenty six (26) percent of the patients were male, fortyfour percent patients were female and thirty percent were pediatric patients. In this study pediatric patients are regarded as patients younger than twelve years.

The higher number of females in this study is because it is the function of females to collect water at the river. This is a traditional function in the Kavango region. Unfortunately when conducting this study, a significant number of rebel soldiers from Angola were crossing the river and they also laid antipersonnel landmines.

Many of the female respondents in this study were exposed to these landmines, and thus contributed the larger presentation in this study (Observation by the principle researcher). 


\section{Information on hygiene care}

The study provided the following results based on the observations of the various hygiene aspects.

\section{Hair care}

Hair care was being evaluated with regard to:

- Cleanliness

- Shiny or not

- Combed or not

- $\quad$ Plaited or not

Plaited hair is regarded as contributing to overall hygiene in some females in the Kavango region.

In 73\% observations it was found that the patients' hair had been washed together with the bed-bath. This result must be seen in perspective. During the week of observations each patient was observed seven (7) times for this particular aspect of hygiene. It is, however, true that many patients may not wash their hair each day.

Although all these patient's hair did not appear to be shiny or combed, they appeared neat and hygienic.

\section{Eye care}

Evaluation on eye care was done with regard to:

- Cleanliness of the conjunctiva

- The presence of eye inflammations or not

Figure 1: Outcome of hair care in percentage of total observations ( $N=30$ )

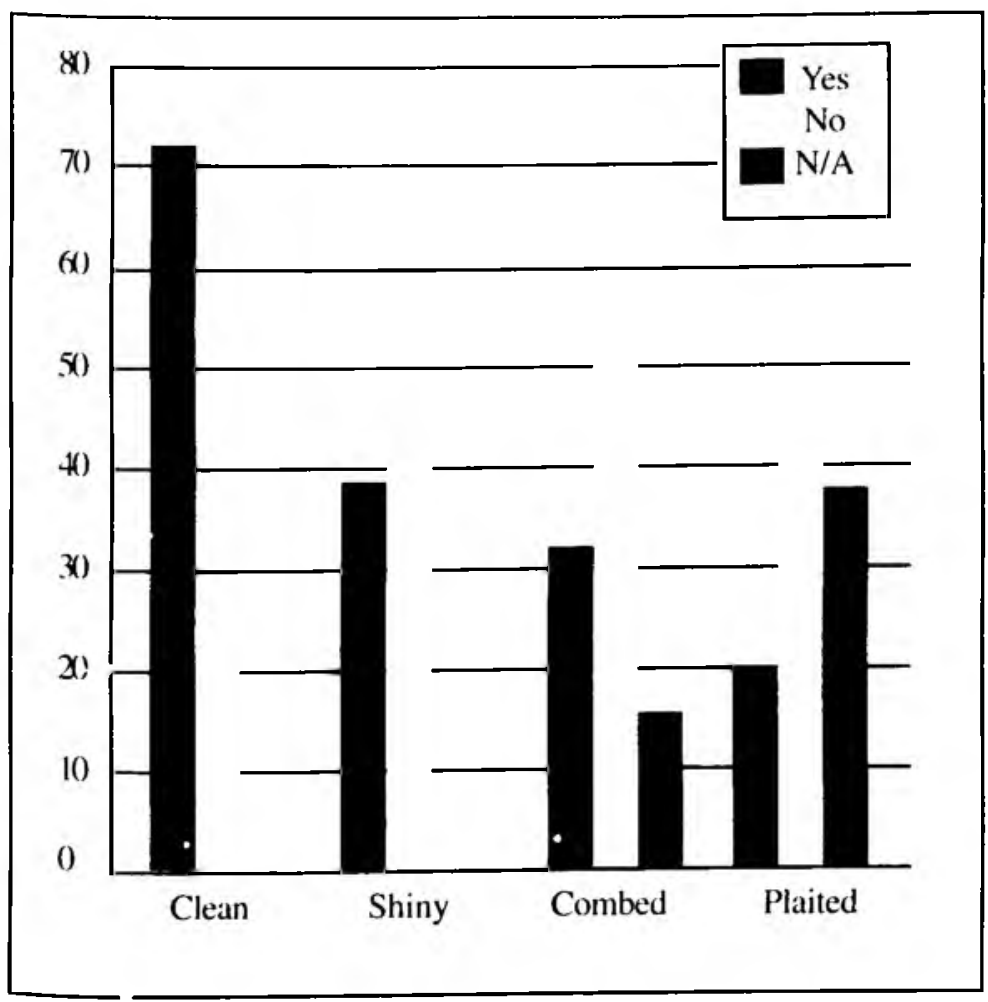

- Watery eyes

- Eye discomfort

Due to the close relationship between inflammatory conditions and discomfort with hygiene, these two aspects were also included. An example is acute conjunctivitis (pinkeye) which is a common bacterial infection caused by Staphylococcus, Gonococcus, Pneumococcus, Haemophilus, or Pseudomonas (Sheehy \& Lenehan, 1999:441). In only nine (9) percent of the observations, patients with watery eyes were found. Ten (10) percent of the patients experienced eye discomfort.

According to Viljoen \& Uys (1998: 542), the abovementioned are warning signs of possible abnormalities.

The high incidence of eye inflammation, namely thirty (30) percent is a matter of concern. These findings were however not recorded in the patient's records. Therefore, it is very difficult for the nursing persornel to intervene.

According to Searle and Pera (1997: 163), recordkeeping is an essential component of the nursing process, and what is not recorded is not done.

\section{Ear care}

The ears were observed for the following:

- Cleanliness

- Excessive ear wax

- Ear discomfort

- Hearing disturbances

- Damage to the ears

- Abnormal discharge 


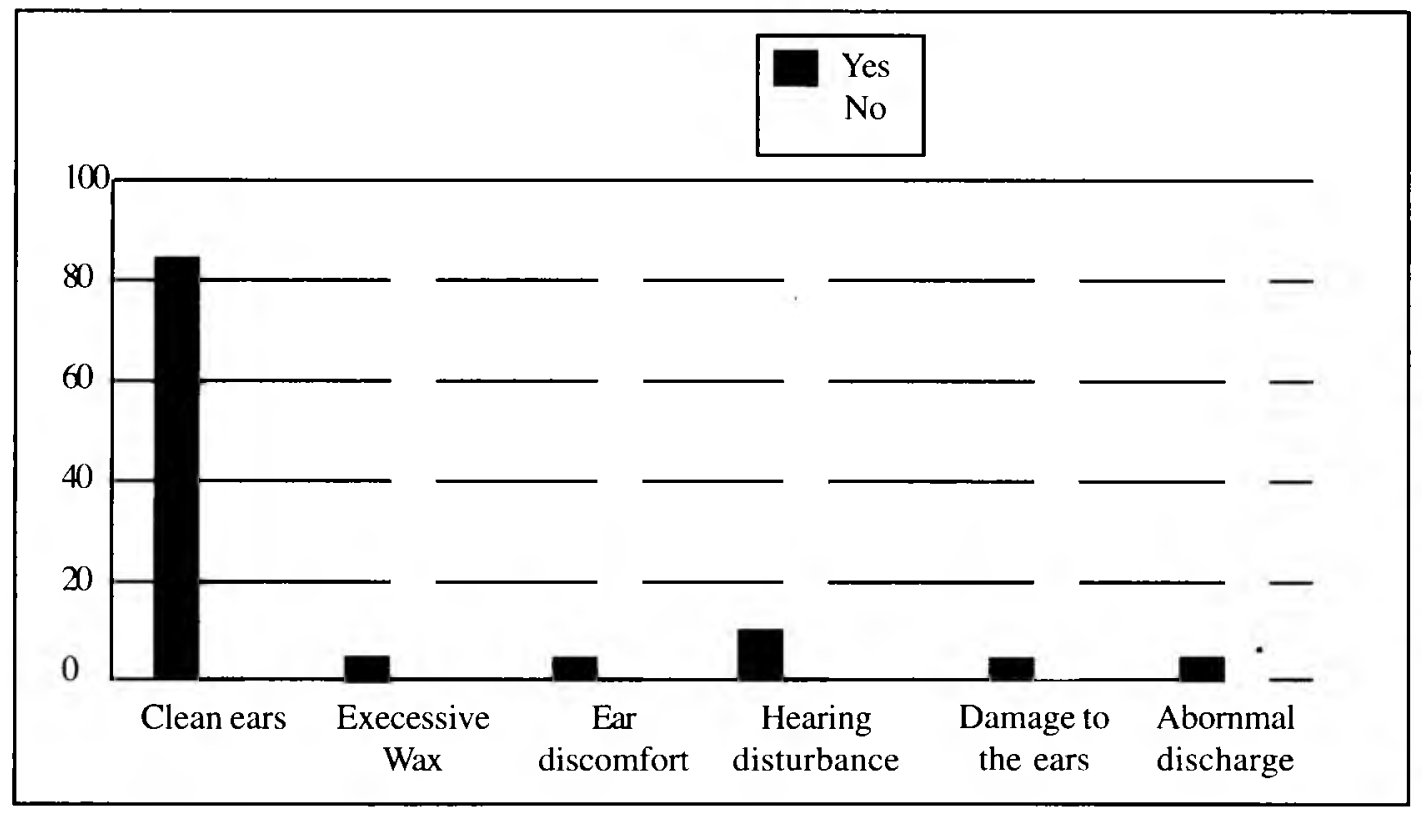

None of these problems experienced were recorded in their records.

\section{Mouth care}

The mouth was observed for the following:

- Cleanliness

- Oral discomfort

- Smooth and dehydrated oral mucosa Inflammation of the oral mucosa

Intact oral mu$\cos a$

- Normal colour

Due to the possibility of unhygienic conditions leading to itching with a resultant scratching and damaging, an item of "damage" was also included. Excessive wax build up in the ears could also lead to hearing disturbances, thus this item's inclusion. The results are graphically displayed in figure 3 .

In eighty two (82) percent of the total observations, the ears of the patients were found to be clean.

In four (4) percent of the patients, excessive ear wax was found. Also in five (5) percent ear discomfort was observed as well as hearing disturbances in seven percent of the patients.

\section{Figure 4 : Outcome of mouth care as percentage of total observations}

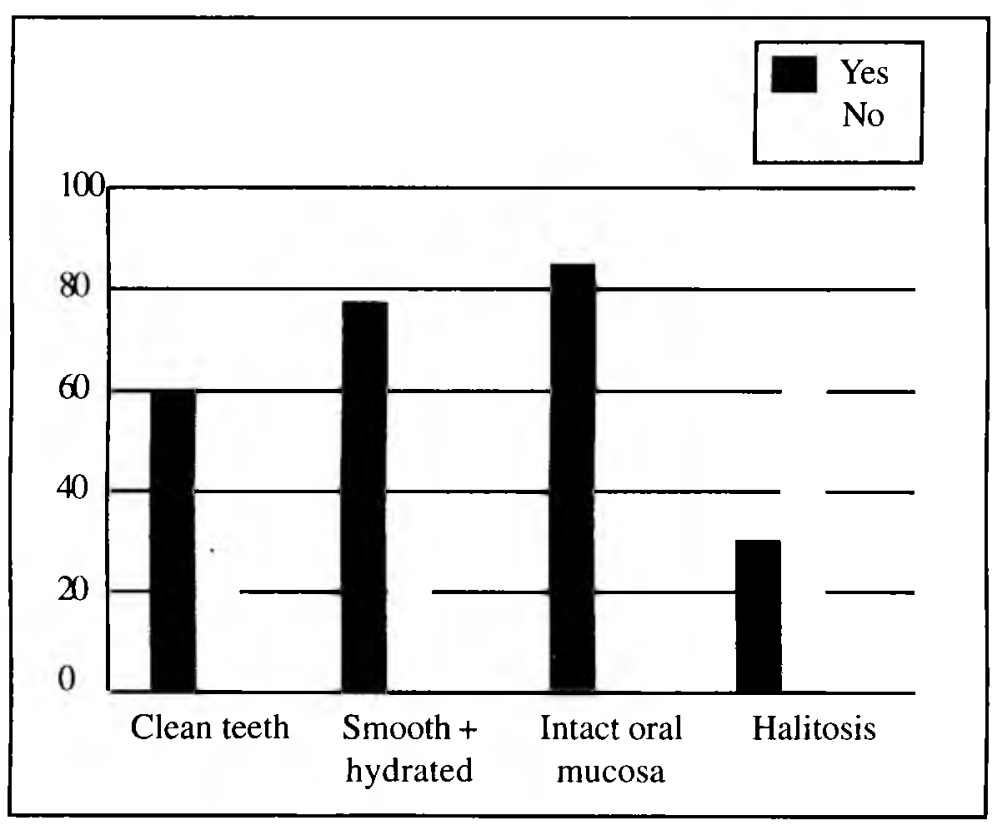

ecord-keeping was also insufficient, and only in forty four (44) percent of the observations reference to these problems were found in patient records.

The high incidence of halitosis, thirty two (32) percent, correlates and is connected with the oral discomfort and unclean teeth. It also affects the patients' general comfort as they may be aware of it as well as their visitors, relatives and health personnel.

\section{Nose care}

The nose was observed with regard to the following:

- Clean nose

- Nose discomfort

- Damage to the nose

- Abnormal discharge

Due to the dry climate in Namibia, it might create a drying effect on the nasal mucosa with a resultant 
Figure 5: Outcome of nose care as percentage of total observations $(\mathbf{N}=\mathbf{3 0}$ )

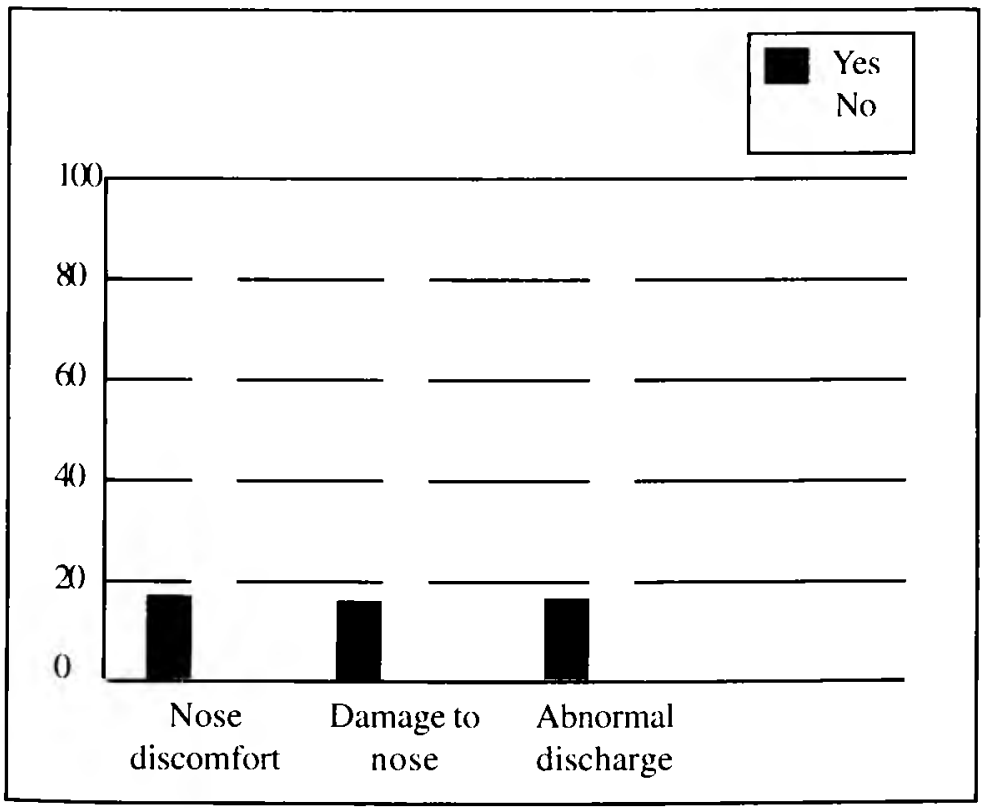

irritation. This could lead to scratching and damage to the nasal structure, which could impede nasal hygiene.

In seventeen (17) percent of the observations, the nose was found not to be clean. This is an anesthetic issue because people in contact with the patient may avoid him or her due to this. It might also interfere with the olfactory (smell) sense.

\section{The skin}

The skin was observed with regard to the following:

$\begin{array}{ll}\text { - } & \text { Smooth } \\ \text { - } & \text { Supple } \\ \text { - } & \text { Good turgor } \\ \text { - } & \text { Warm } \\ \text { - } & \text { Intact } \\ \text { - } & \text { Clean }\end{array}$

All the patients in this study were dependent or semi-dependent on the assistance of the nurse. In eighty three (83) percent of the observations, the patients indicated, and it also appeared evident through observations, that the patients had received a bed-bath. Despite the high percentage obtained, an acceptable norm would be closer to a hundred percent as a daily bed bath is regarded as an absolute minimum requirement. This apparent shortcoming in providing bed-baths to every patient each day may account for the high incidence where the skin did not appear to be smooth, namely in thirty eight (38) percent of observations. In all the remaining aspects to be evaluated, a compliance of above eighty (80) percent was obtained.

\section{Beard care}

The patients were observed to see whether their beards were:

- Shaved

- Groomed

As can be seen in figure 6 , during eighty $(80)$ percent of the time, the patients were not shaved, despite their willingness to be shaved.

Patient's physical appearance is negatively influenced when unshaven, especially in the first two days. If patients are not accustomed to it, it may create a feeling of not being "groomed".

\section{Hands, nail and foot care}

The hands, nails and feet of patients were observed with regard to the following:

- Nails (short and clean)

- Pink nails beds

- Inflammation (Feet)

- Smooth nail edges

The fact that most of the people in the Kavango region walk bare feet could be the contributing factor of inflammation as also is indicated in figure 7

\section{Perineal care}

During this part of the hygienic evaluation, observations were done with regard to:

\section{Figure 6 Outcome of beard care as percentage of total observations $(\mathbf{N}=\mathbf{3 0})$}

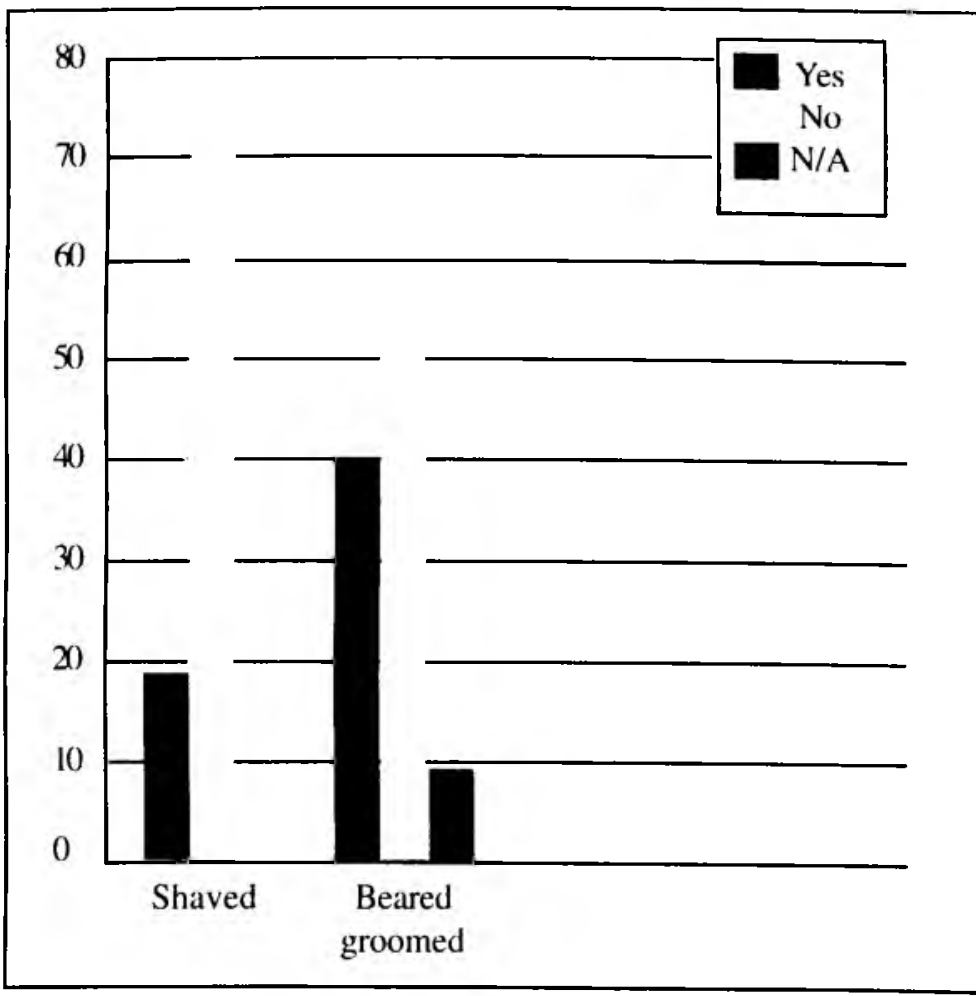


Figure 7 Outcome of hand nails \& feet care as percentage of total observations $(\mathrm{N}=\mathbf{3 0})$

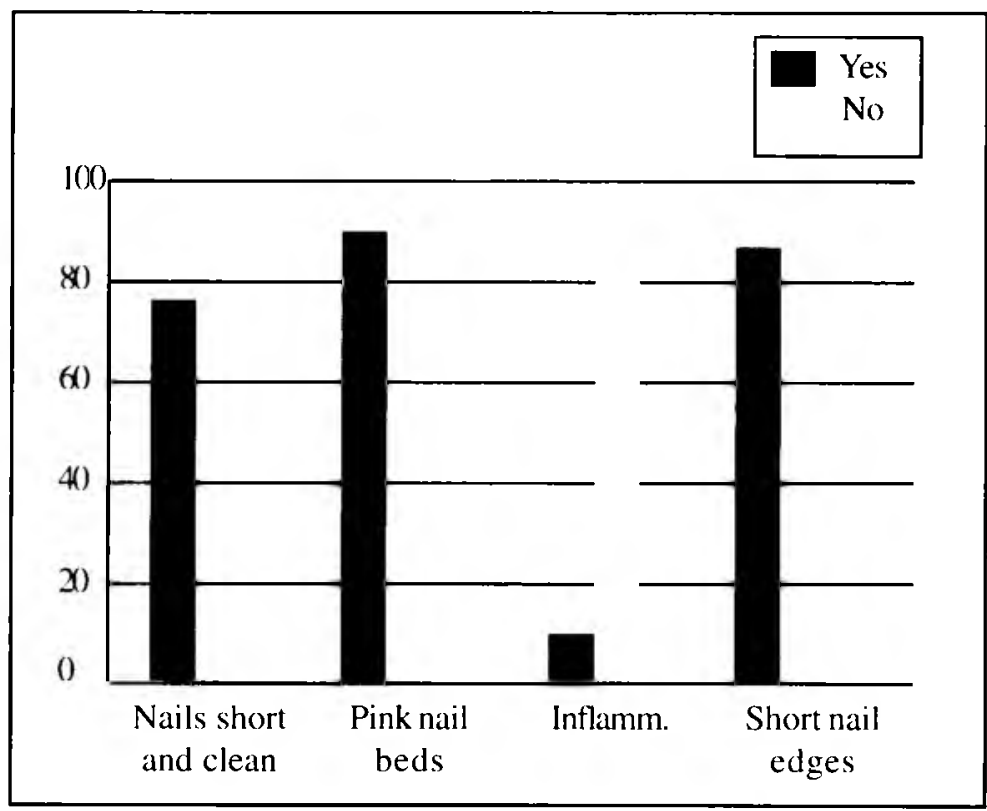

ily result when hygienic care is sub- optimal, even the slightest deviation should be noticed (Sheehy \& Lenehan, 1999: 327).

This is even more important due to the fact that many of these patients already have full blown AIDS and their immune system is severely compromised.

\section{Appropriate nursing actions taken}

Patients' records were scrutinized to confirm if appropriate nursing actions were taken. As can be seen in figure 9 , this was not the case. If nothing was recorded, it was regarded as not being done.

According to Searle a nurse betrays the relationship with her patient when she is lax in maintaining records (Searle, 1991: 86).
- $\quad$ Presence of itching;

- $\quad$ Signs of discomfort;

- $\quad$ Presence of abnormal discharge.

Although few abnormal observations were noted as can be seen in figure 8 , the researcher did, however, notice the following:

- $\quad$ Perineal care was not done during the bed bath; and

- $\quad$ Nothing was recorded.

As the spread of micro-organisms to the bladder could eas-

\section{Figure 8 Outcome of perineal care as percentage of total observations $(\mathbf{N}=\mathbf{3 0}$ )}

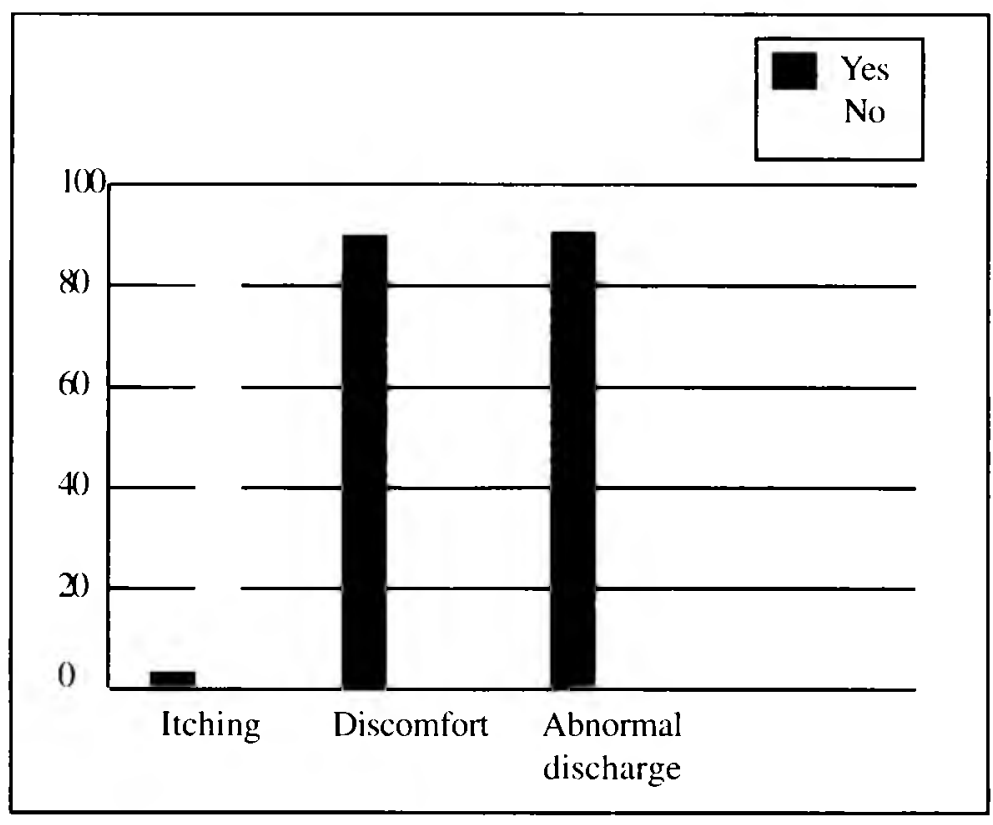

\section{Recommendations to improve the quality of hygienic care}

Recommendations were made with regard to in-service education, nursing management and further research.

\section{In-service education}

Education is defined by Mellish \& Brink ( 1996:76) as a process of leading the person being educated from a state or not knowing, to a state of knowing. In-service education refers to training received by the nursein practitioner inside the working environment and which is directly related to the work (Muller, 2002: 344).

Following this study it is recommended that all categories of nurse be subjected to in-service education programmes. This will enable them to better integrate theory and practice.

Emphasis should be placed on responsibility and accountability as is deducted from the scope of practice as stipulated in the Nursing Act, Act No. 30 of 1993 (Namibia, 1993: 1-10).

Furthermore it is necessary to instill a caring attitude or philosophy. It is the perception of the researcher that some of the inadequacies in hygienic care could be attributed to a lack of care. As Watson put it: "The practice of caring is central to nursing" (Watson, 1995:318).

\section{Nursing management}

The management of patient care needed to be strengthened. 
Figure 9 Appropriate nursing action taken for each part of care personal hygiene as percentage of total observation ( $\mathbf{N}=\mathbf{3 0})$.

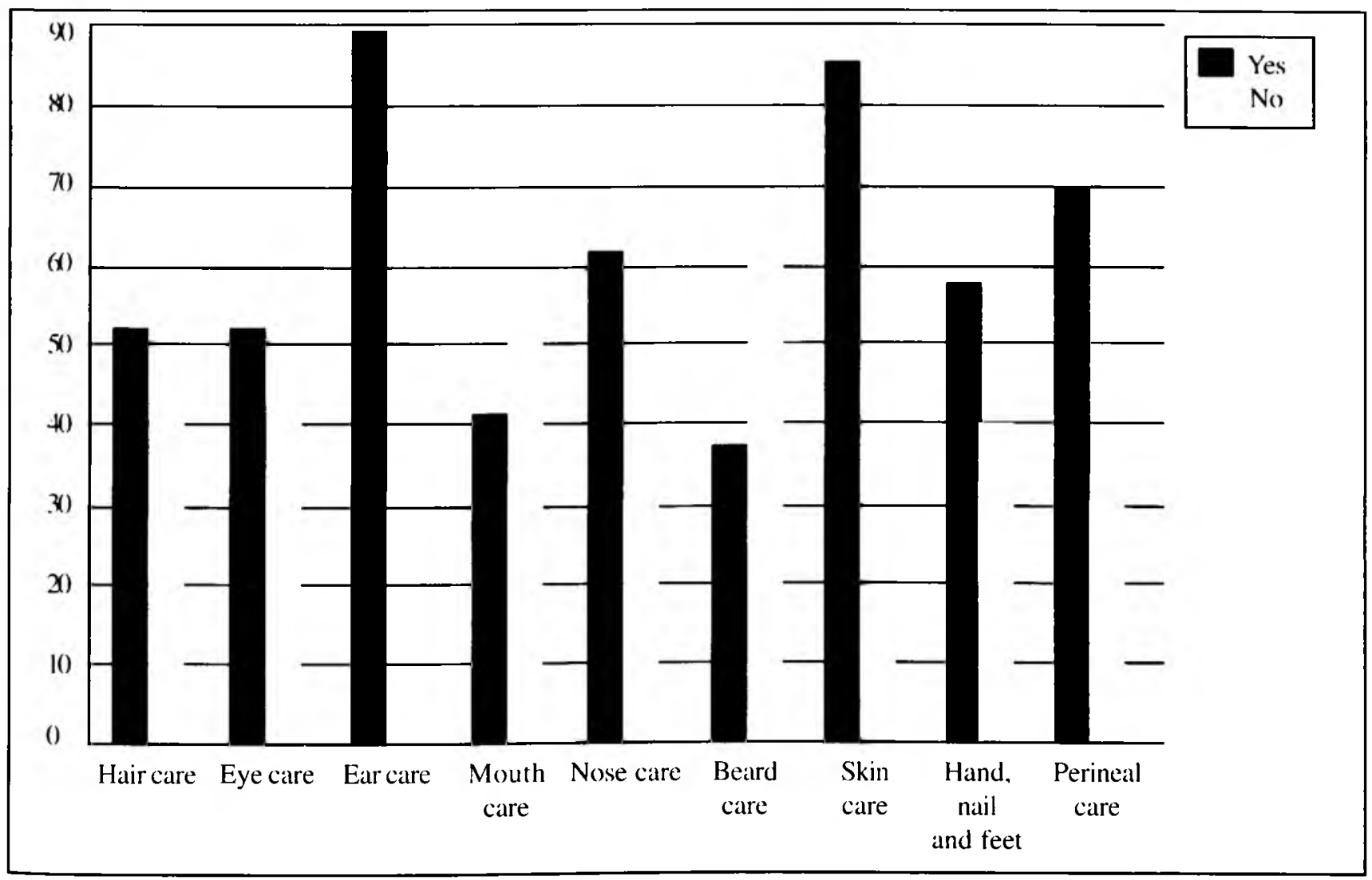

It was observed during this study that a lack of supervision existed based on the fact that auditing of patient files was not done. Consequently nursing actions taken could not be compared to the expected outcome. Thus it is recommended that regular patient record audits be done.

It was also recommended that regular quality control meetings be held between managers and registered nurses.

\section{Further research}

It was recommended that patient evaluations be done before discharge in order to obtain patient assessment of the quality of care.

A public relation officer could be appointed, made known to the public, to whom the members of the community could go with their concerns.

As this study was limited to one hospital, it is recommended that similar studies be done in all the hospitals in Namibia. Further studies should also be conducted during which time standards could be formulated.

\section{Limitations of the study}

There were limitations with regard to the study population as well as the working environment.

\section{- The study population}

For this study to be effective a minimum number of patients were required in order to obtain reliable statistical data.
These patients had to be observed for a period of at least seven (7) days each. As this is an endemic malaria area, patients may be admitted only for 3 - 4 days and then will be discharged. Thus a very specific population was studied, namely hemiplegic patients, HIV/AIDS patients and patients who had had amputations.

\section{- Working environment}

The political instability in Angola caused an extra burden on the workload of the nurses. All the war victims in Angola as well as in Namibia were referred to the regional hospital where the study was conducted. This could have created an additional physical and emotional burden.

\section{Conclusion}

The results of the study highlighted some shortcomings in hygienic care. These shortcomings are regarded as easily rectifiable by means of in-service education and optimum management by the nursing managers. Quite often, aspects of care were indirectly negatively influenced by a lack of proper recordkeeping. This aspect has legal implications and should also be address d in earnest.

\section{List of References}

GORION, D; LARSON, TJ \& MCGURK, CR 1981: The Kavango peoples. Studien zur kulturkunde. Wiesbaden: Franz Steiner Verlag.

NAMIBIA (REPUBI IC) 1993: Government Gazette of the 
Republic of Namibia. Government Notice no.3, Nursing Professions Act 1993. Windhock: Government publishers.

MEI.IISH, JM \& BRINK, H 1996: Teaching the practice of nursing. A text in nursing didactics. $3^{\text {rd }}$ ed. Johannesburg: Heinemann.

OXFORD DICTIONARY, 1990: Oxford: Clarendon Press.

SCHILIING, C (PUBLISHER) 2002: Pathophysiology made incredibly easy. New York: Lippincott Williams \& Wilkins.

SEARI.E, C 1991: Professional practice. A South African perspective. I $^{\text {st }}$ ed. Durban: Butterworth's

SEARI,E, C \& PERA, SP 1997: Professional Practice A Southern African Nursing Perspective. Third edition. Durban: Butterworhs

SHEEHY, SB \& I.ENEHAN, GP 1999: Manual of emergency care. $5^{\text {th }}$ ed. New York: Mosby

VAN DYK, A; SMALL, I.F; HAOSES, L \& ACKERMAN, MJ 1993: An evaluation of the quality of nursing care rendered to patients to patients with intravenous infusion in the Windhoek Hospital Complex . Curationis. 17 (3)

VII.JOEN, MT \& UYS, R 1998: General Nursing Medical and Surgical Textbook Part 2 .Pretoria: Kagiso.

YOUNG, A; VANNIEKERK,CF \& MOGOTLANE,S(EDITORS) 2003: Juta's Manual of Nursing. Volume 1. Lansdowne, Juta \& Co.

WATSON, J. 1995 in: Nursing theories. The base for professional nursing practice Nursing. Editor: George JB. $4^{\text {th }}$ ed. London: Prentice Hall. 